\author{
Asian Journal of \\ Medical and Biological Research \\ ISSN 2411-4472 (Print) 2412-5571 (Online) \\ www.ebupress.com/journal/ajmbr
}

\title{
Article \\ A case study of the gears and craft used for artisanal fishing in Chittagong Patharghata Fishery Ghat, Bangladesh and socio-economic condition of the fishermen
}

\author{
Mohammad Rashed $^{1}$, Md. Abul Hossain ${ }^{2}$ and Mohammad Matiur Rahman ${ }^{1 *}$ \\ ${ }^{1}$ Department of Fisheries Biology and Genetics, Bangladesh Agricultural University, Mymensingh, Bangladesh \\ ${ }^{2}$ Department of Fisheries and Marine Science, Noakhali Science and Technology University (NSTU), Noakhali- \\ 3814, Bangladesh
}

*Corresponding author: Dr. Mohammad Matiur Rahman, Department of Fisheries Biology and Genetics, Bangladesh Agricultural University, Mymensingh-2202, Bangladesh. Tel.: +880-91-67401-06/Ext. 2911 (Office); E-mail: rahman.matiur@bau.edu.bd

Received: 10 November 2016/Accepted: 05 December 2016/Published: 29 December 2016

\begin{abstract}
The Patharghata Fishery Ghat in Chittagong is one of the largest fish landing centers in Bangladesh. The study aimed to explore different types of gears and crafts used from the landing center, fish species caught by the gears, and certain degree of socio-economic condition of the fishermen. Data were collected from local fishermen through on the spot inspections, Personal Interview (PI), and Focus Group Discussion (FGD). The gears used from the landing center were classified as Large Mesh Drift Gill Nets (DGNs), Marine Set Bag Nets (MSBNs), and Trammel Nets. Mainly 7 types of DGNs having the mesh sizes ranging from 2.5 to 16 inches had been used by the fishermen of which Lakkha Jal, Lal jal and Char Shuta Jal were the most commonly used DGNs to catch Hilsha, Lakhua, Pomfret etc. Hilsha Shad (Tenualosa ilisha) was the most dominant species and about $60 \%$ of different nets were used to catch this species. Only single type of artisanal fishing craft (trawlers) was found in the landing center and is propelled by inboard engine. The capacity of the trawlers varied from 8 to 22 metric tons. In case of socio-economic condition, most of the fishermen belonged to the age groups of 21-30 and 31-40 years; each represented $31 \%$ of the total fishermen. About $91 \%$ of fishermen were found to be Muslim and rest 9\% were Hindu. The average members of the nuclear and joint families were 3.78 and 7.83 per household, respectively; however, these groups of people were being deprived in their society. The study also revealed that about $67 \%$ of fishermen had no formal education and $27 \%$ had primary and rest $6 \%$ had secondary level of education. The annual income of the fishermen ranged from BDT 50,000 to 100,000 and the main expenditure of their earnings were for food $(80 \%)$, followed by physical treatment $(10 \%)$ of their family members. They had hardly any savings. Lack of knowledge and government support, and illiteracy were the major problems of the fishermen in the landing center.
\end{abstract}

Keywords: fishing gears; crafts; species caught; socio-economic condition

\section{Introduction}

Fish and fisheries items have been providing food or animal protein for millions of poor people in Bangladesh (Akter et al., 2012). The total fish production in Bangladesh accounts for 3.548 million metric tons in 2013-14 fiscal years (APCAS, 2016). It accounts for 3.69\% of the GDP and 2.01\% of exports in 2013-14 (APCAS, 2016) and supplies about $60 \%$ of the animal protein intake for total population of the country. The country's marine fish catch in 2013-14 was 0.595 million metric tons and inland fisheries accounted for the bulk of fish production of about 2.953 million metric tons (APCAS, 2016). Since few years back, there had been an increase in the landings of marine and estuarine fishes. The Patharghata Fishery Ghat in Chittagong is one of the biggest landing centers of different estuarine and marine fish species in Bangladesh. This landing center alone handles 
more than $90 \%$ of the total fish landed in Chittagong. The landing center has four fish landing points. While one point is operated by the Chittagong City Corporation, the other three are leased by the Chittagong Port Authority to private parties. The fishermen of the Ghat mainly catch fish from the major four fishing grounds of the Bay of Bengal. These are South Patches, South of South Patches, Middle Ground and Swatch of no Ground. Different types of fishing gears are found in the landing sites which are used to catch different types of estuarine and marine species. Fishing gear is any form of equipment, implement, tool or mechanical device used to catch, collect or harvest fish. The principal categories of fishing gears that are traditionally used in Bangladesh can be categorized as the following: fishing nets, fishing traps, hooks and lines, wounding gears and fish aggregation device (Chakraborty et al., 1995). Various types of materials are used to make these fishing gears include netting, twine, plastic structural and fasteners, clips and swivels, ropes, steel wire ropes, combination wire ropes, purse rings, polyester, polyethylene, nylon, cotton, polypropylene, mixed fibers, floats and sinkers, bamboo, wood etc. (Hameed and Boophendranath, 2000). In this landing center, various types of fishing nets are found which are used for catching fish. But it is unfortunate that there is no actual data on the types and specification of those nets. Specific types of crafts are needed to regulate specific nets for proper handling. The data on the specification of gears would make it easier for the local authority in making policy for effective fishing without harming fisheries resources.

In case of fisheries resources, fisherman is one the most important components. Many fishermen are involved in catching fish in Bangladesh. Greater percentages of them are inland fishermen and the rest are dependent on the marine fisheries sector. Socio-economic condition of the fishermen is of great importance for knowing their actual condition. The socio-economic aspect describes the status of income, expenditure, housing condition, health and sanitation, education, family structure and other economic condition. Some of the most commonly used factors in the assessment of livelihood security included household income and expenditure, expenditure spent for food, adequacy of food taken, household structure and facilities, access to drinking water and sanitation, and other basic needs of farm household. For planning, decision making and developing the fisheries sector, it is necessary to know the socio-economic condition of the related people. Besides the socio-economic condition of the fishermen and intermediaries of this sector are also changing day by day. For this reason it is necessary to know the present socio-economic condition of the fishermen and intermediaries. Compared to inland fewer studies have been done on the socio-economic status of the fishermen of marine areas of Bangladesh. Because of inadequate research data there is still huge gap in between actual condition and various policies taken on this field. A study has pointed out that the fishermen are dissatisfied with their meagre income and arguably describe it as a story of untold misery (Alam et al., 2007). Many other researchers have identified rural power structure and local politics and government leasing system as sources of all conflict (Ghani et al., 2008; Bennet and Chattermoul, 1998; Bob, 1996). Hussain (2010) found that majority of the participants were not satisfied with their current income and a significant number of them want to change their occupation. Another study reveals some social aspects of a special group of fishing people i.e. fishermen of Moheshkhali Island, as for instance, their indigenous knowledge of fishing, religious belief, rituals, trading and marketing system of fishes etc. and to some extent explores the exploitation of the fishermen by the boat owners (Uddin, 2000). The dissatisfaction comes due to the deprivation of the society. As stated earlier more than $90 \%$ of marine fishes are landed in the Ghat only because of the untiring work of the fishermen. So, it is important to understand how they are living, what is their family background, how the policies are affecting their livelihood. The study of the socio-economic condition of the fishermen of the Patharghata Fishery Ghat will demonstrate the occupational status, annual income, educational status, health facilities, family size and type, sources of income, sanitary facilities and electricity facilities etc. Hence, some policy guidelines can be established to combat the challenges and promote their general well-being.

\section{Materials and Methods}

The study was carried out from January to February 2015 and the primary data were collected through direct survey using questionnaires prepared for the purpose. The fishermen of the study area were asked questionnaire query to get rational answers. The secondary data were collected from literature review and related articles. Local authority in fisheries sector supplied some information; however, those were not adequate.

The primary data had been collected from Chittagong fishing harbor, the Patharghata Fishery Ghat, Kotuali Thana, Ikbal Road, Chittagong (Figure 1). This is the biggest fish landing center in Chittagong. These fishermen when asked about the gears and crafts and their socio-economic conditions, they were able to understand the questions and answered accordingly. More than 50 fishermen were interviewed during the data collection procedure. Care was taken so that respondents did not work for same company or boat owners. Also, when interview of the fishermen and/or boat sailors were done it was ensured that they were not with their employer. 
Questionnaires had been designed on the basis of the objectives of the study. During interview, the new information, when came up, was accepted and further modifications was brought to get the final questionnaire pattern. The sequences of the questions had been in the form that the fishermen felt comfortable while answering. Both open and closed system questions had been attached to the questionnaires. Pilot survey had been conducted to determine the efficiency of the questionnaires. For obtaining detail information about the socio-economic conditions of the fishermen, the data of the parameters such as sex, age group, religion, fishermen from different districts, marital status, family type, number of family members, housing condition, electricity facilities, education level of fishermen, alternative occupation, annual income, annual expense, area of expenses, and savings etc. were collected. The key informants who were interviewed include inspector of the locality and the boatmen of the fishing boats. The interviews were based on the objectives of the study related to different types of fishing gears and crafts, materials, fish species caught, operation, carrying capacity and the socio-economic condition of the fishermen.

\section{Results}

Result has been divided into two sections: one is about the types of gears and craft used in the Patharghata Fishery Ghat and another is about the socio-economic condition of the fishermen. The types of fishing gears used varied according to the types of fishing operation and target species. In case of socio-economic condition, the study focused on personal information and way of living of the fishermen including income and expenditure.

\subsection{Fishing gears and crafts}

Based on fish species caught, their compositions and mode of operation, there were mainly three types of nets found to be operated from fishery Ghat and were mainly used in the estuary and occasionally in open sea. These were Large Mesh Drift Gill Net (DGN), Marine Set Bag Nets (MSBN) and Trammel Nets. In case of fishing craft, there was mainly single type of fishing craft found in the Ghat which was called fishing boat or only boat.

\subsubsection{Large Mesh Drift Gill Nets (DGNs)}

Large Mesh Drift Gill Nets were the most common type of nets found in the Ghat. Various types of nets comprise this group which varied in mesh size, depth, length and catch composition of the species. Among them Lakkha Jal, Lal Jal and Char Shuta Jal are the most frequently used DGNs in the Ghat.

\subsubsection{Lakkha Jal}

Lakkha Jal, the 60 inches cotton twine net is named after the main species caught Lakhua (Figure 2C). The length and width of the net is $5000 \mathrm{~m}$ and $12 \mathrm{~m}$, respectively having mesh size of 12-16 inches. About 6.35-7.26 metric tons of Lakhua fish are harvested by this net during off season; whereas, 18.14-27.22 metric tons and 90.72 metric tons are caught during moderate and peak season, respectively. The net is placed in the open sea in drifting condition for about 5 to 6 hours. The placement requires only one hour but the hauling of the net requires more than 10 hours. Usually, 20-22 fishers are needed to operate the net. Besides Lakhua various types of other species such as Lined Silver Grunter, John's Snapper, Talang Queenfish, Mangrove Red Snapper etc. are also caught by the net (Table 1).

\subsubsection{Lal Jal}

Another important type of DGN is Lal Jal which is made of red cotton twine (Figure 2A). The length and width of the net is $10000 \mathrm{~m}$ and $15 \mathrm{~m}$, respectively with the mesh size of 4 to 8.5 inches. The catch per haul of the net is up to 100 tons during peak season. About 22 men are needed to operate the net. The placement of the net requires more than one hour and the hauling needs more than ten hours. The main target species of the net is Hilsha Shad (Tenualosa ilisha). But various types of other species i.e., Indian Mackerel, Chinese Pomfret, Moon fish, Ribbon fish, Goatee Croaker, and Bombay Duck etc. are also caught by the net (Table 1).

\subsubsection{Char Shuta Jal}

Char Shuta Jal is the most effective DGN for harvesting Hilsha fish. It is one of the largest nets found in the Ghat and made up of white twine. The length of the net is usually $10000 \mathrm{~m}$ whereas width is only $12 \mathrm{~m}$ having mesh size of 2.5 to 3 inches (Figure 2D). The placement and hauling time are as same as Lal Jal. The catch per haul of the net is more than 90.72 metric tons during peak season. About 18-20 men are engaged in operating the net. Besides Hilsha the fish species caught by this net are shown in Table 1. 
3.1.1.4. Vasha Jal

Vasha Jal, a rectangular shaped net made of white cotton twine is used mainly to catch Hilsha Shad (T. ilisha). 'Vasha' means floating which indicates that it is used in the surface layer of water body. It is $42-45 \mathrm{~m}$ long and 20-25 m width having a mesh size of 4-4.5 inches. Generally five to six fishermen are needed to handle this net (Table 1). This net is mainly used in comparatively small sized fishing boats. Besides Hilsha fish some other species, such as Croakers and Pomfrets are also caught by this net.

\subsubsection{Ton Jal}

Ton Jal is another Hilsha fish catching net which is smaller than Vasha jal and made up of cotton twine. It is 12$15 \mathrm{~m}$ long with the depth of 7-10 m having mesh size between 2.5 and 3 inches. Generally small sized Hilsha are caught by this net. In Hilsha boats, usually, more than one net is operated from a fishing boat. Roughly three to four fishermen are required to operate the net. It is mainly used in the estuarine region. Rita (Rita rita), Bata (Liza subviridis) and Opal fish (Bembrops caudimacula) are also caught by this net.

\subsubsection{Illish Jal}

Illish Jal, named after the prime species caught, the special type of net that is used mostly for catching hilsha fish (Figure 2B). The net is made up of nylon rope, polypropylene or polyamide monofilaments. This net is one of the largest nets found in the Ghat with the length and width of about 1250-2500 m and 10-25 m, respectively. The mesh size is medium in comparison to Vasha jal and Ton Jal, ranging between 3 and 3.5 inches (Table 1). Floats and sinkers are used so that the net can be drifted in the water column and gills of Hilsha fish are trapped into the mesh of the net. The number of fishers required to operate this net are 7-10 per net. Construction cost of this net is $25,00,000$ to $30,00,000$ BDT having a life span of 7 to 15 years. The net is operated from the boat and generally used throughout the whole year except the fish banning period.

\subsubsection{Maitta Jal}

Maitta Jal or Maitya Jal is another type of drift gill net used mainly to catch Maitya fish, commonly called Indian Mackerel (Rastrelliger kanagurta). Some other fish species are also harvested by the net namely Churi or Smallhead Hairtail (Eupleurogrammus muticus) and Chotpoti fish. The length of the net is about 2000 meter and width is $16 \mathrm{~m}$ having mesh size ranging from 4 to 4.15 inches. Net material is made of polyamide monofilaments and nylon rope or cotton twine. Usually, 6-8 persons are needed to operate the net.

\subsubsection{Hangor Jal}

Hangor Jal is a long net used in the drifting condition and its one edge is attached to the boat. As the name expresses, the net is used to catch hangor (sharks). The net ranges from 2500 to $3000 \mathrm{~m}$ in length and $12 \mathrm{~m}$ in width having bigger mesh size of 12 inches. Generally 15 to 20 fishers are required to handle the net (Table 1). Although mainly Starspotted Smooth hound shark (Mustelus manazo) is expected to be caught by this net because of its economic value, but various types of other sharks species including Lakhua (Leptomelanosoma indicum), Mud Skate (Rhina ancylostoma), Leopard Stingray (Hamantura uarnak), and Bluespotted Stingray (Dasyatis kuhlii) etc. are also caught by this net.

\subsubsection{Moda Jal}

This type of net is prepared by the wide cotton twine with the mesh size of maximum 12 inches. Mainly two types of fish such as Lined Silver Grunter (Pomadasys hasta) and Lakhua (L. indicum) are caught by the net. The length of the net varies from $400-500 \mathrm{~m}$ and width $12 \mathrm{~m}$. Generally, 10-15 people are needed to manage the net.

\subsubsection{Trammel Net}

Trammel nets are also called trap net or three layered pocket nets. Trammel nets are three paneled bottom set gill nets with outer $1.8 \mathrm{~m}$ panels of large meshes (10.43 inches) and an inner loose $2.25 \mathrm{~m}$ panel with small mesh (1.97 inches). These nets are operated by using an 8-10 m long, open wooden dinghy-type, nonmechanized sail boat. Trammel nets are specialized bottom gill nets placed at sea bottom with the help of sinks and floats. There are mainly two types of trammel nets, called Pondora Jal and Tong Jal which were found in the Fishery Ghat. 


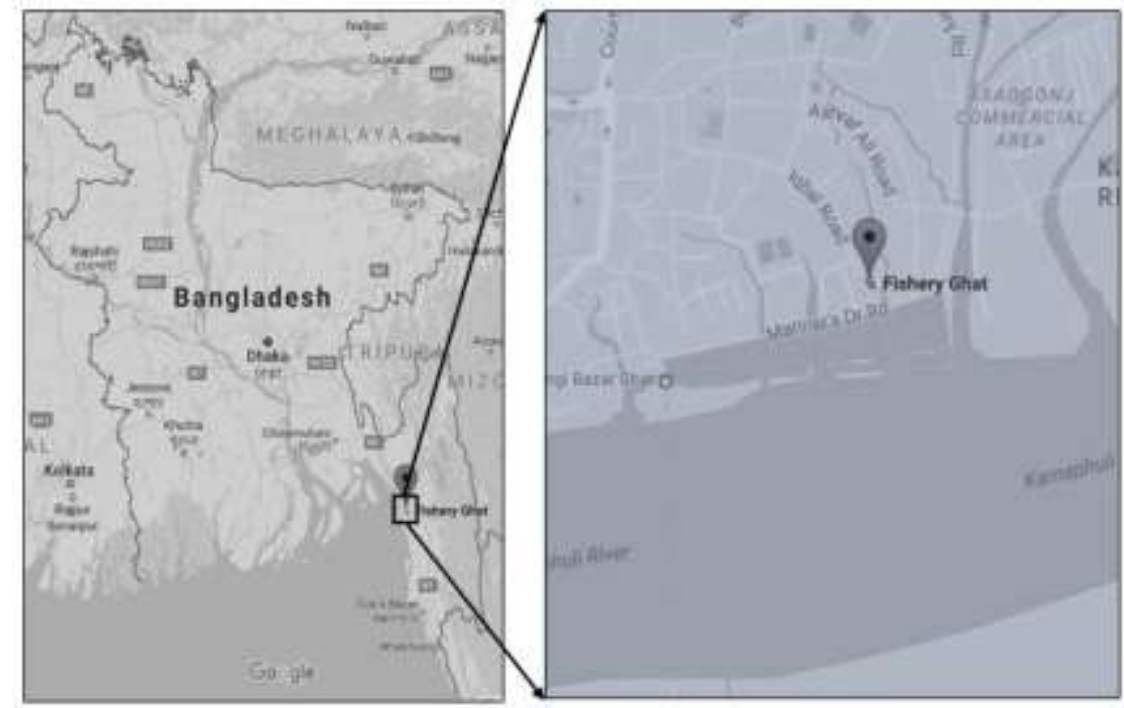

Figure 1. Map of study area.

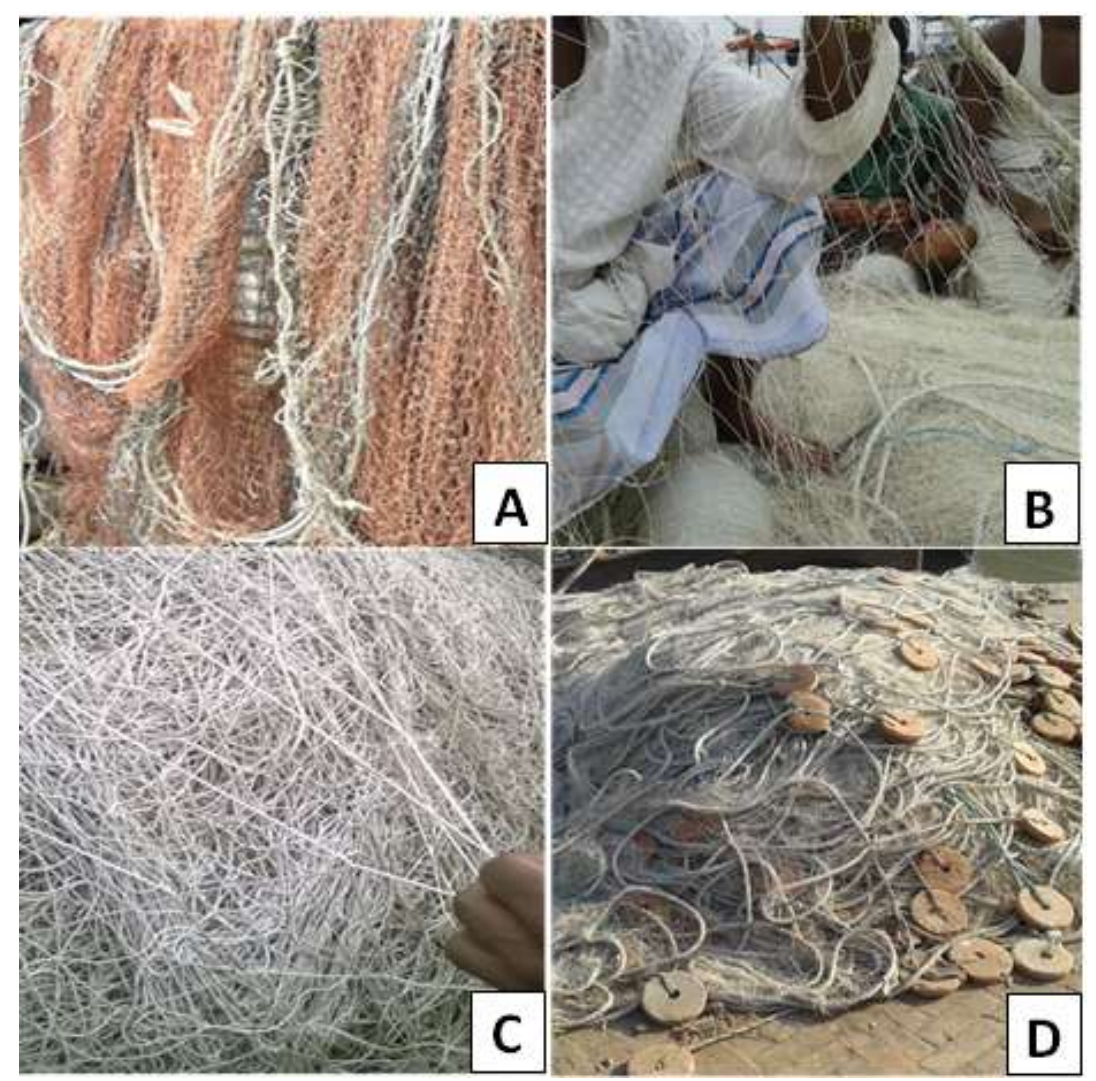

Figure 2. Major four types of nets, (A) Lal Jal, (B) Illish Jal, (C) Lakkha Jal, (D) Char Shuta Jal 


\begin{tabular}{|c|c|c|c|c|c|c|c|c|c|c|c|c|}
\hline \multirow{2}{*}{\multicolumn{13}{|c|}{\begin{tabular}{|l|l|} 
Net Month \\
Illish Jal
\end{tabular}}} \\
\hline & & & & & & & & & & & & \\
\hline \multicolumn{13}{|l|}{ Lal Jal } \\
\hline \multicolumn{13}{|l|}{ Lakkha Jal } \\
\hline \multicolumn{13}{|l|}{ Char Shuta Jal } \\
\hline \multicolumn{13}{|l|}{ Behundi Jal } \\
\hline \multicolumn{13}{|l|}{ Hangor jal } \\
\hline \multicolumn{13}{|l|}{ Moda Jal } \\
\hline \multicolumn{13}{|l|}{ Ton Jal } \\
\hline \multicolumn{13}{|l|}{ Vasha Jal } \\
\hline Current Jal & & & & & & & & & & & & \\
\hline
\end{tabular}

Figure 3. Seasonality map of different nets.

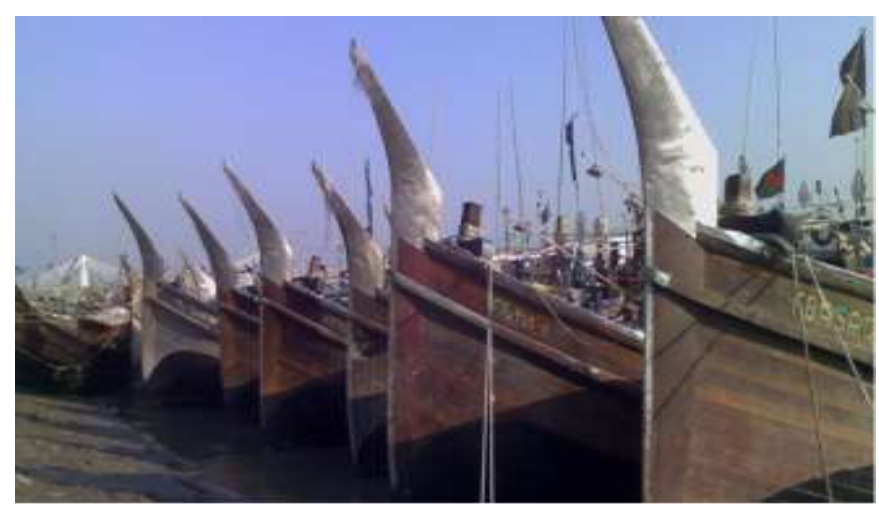

Figure 4. Fishing crafts found in The Patharghata Ghat, Chittagong.

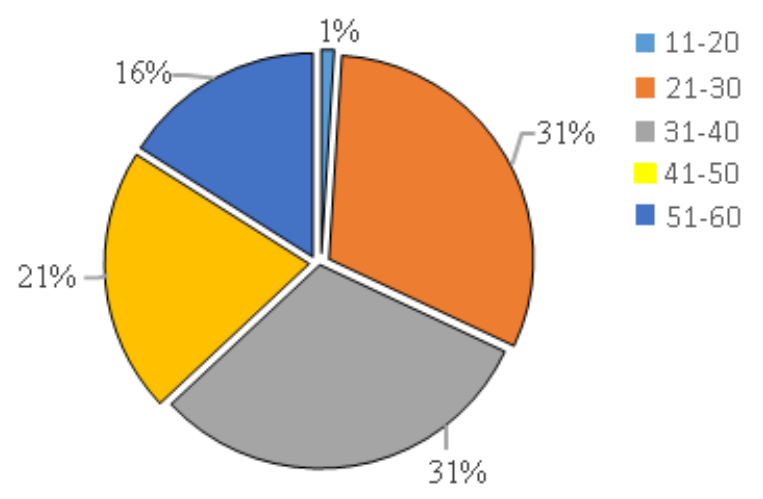

Figure 5. Age group of fishermen. 


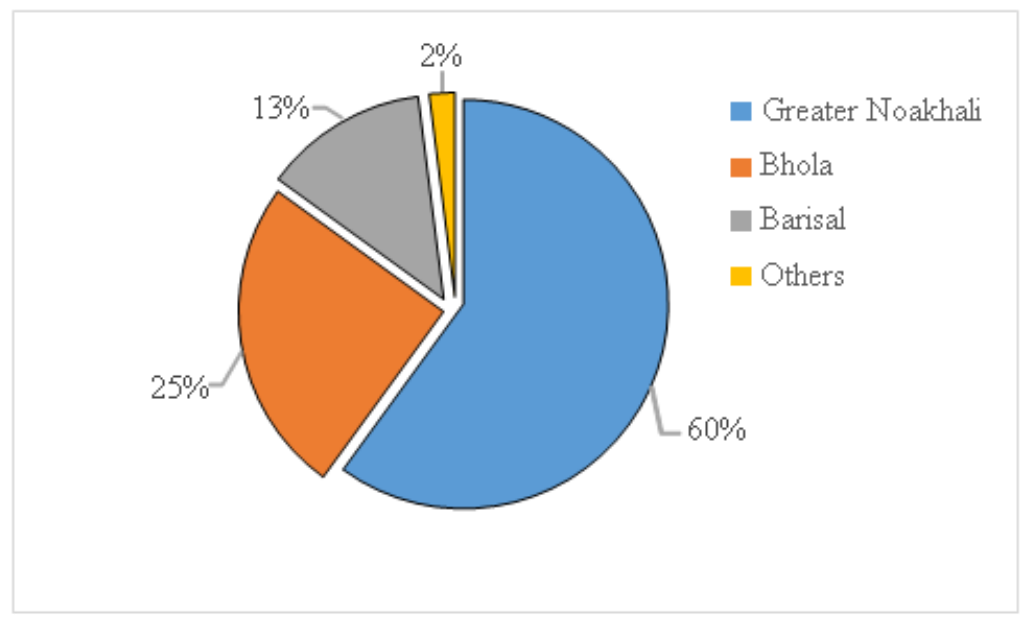

Figure 6. Fishermen from different districts.

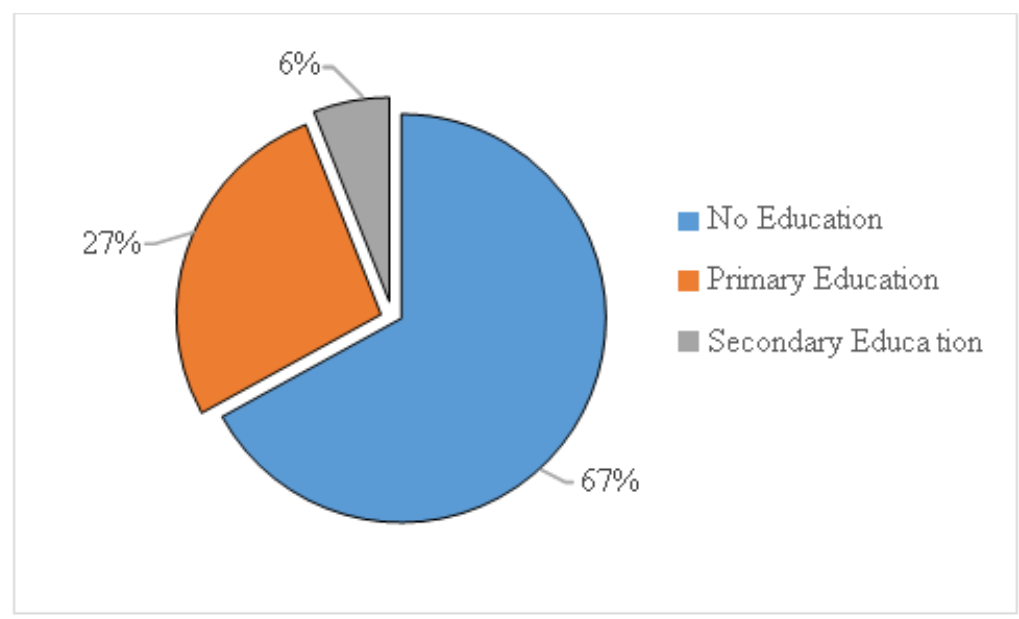

Figure 7. Level of education.

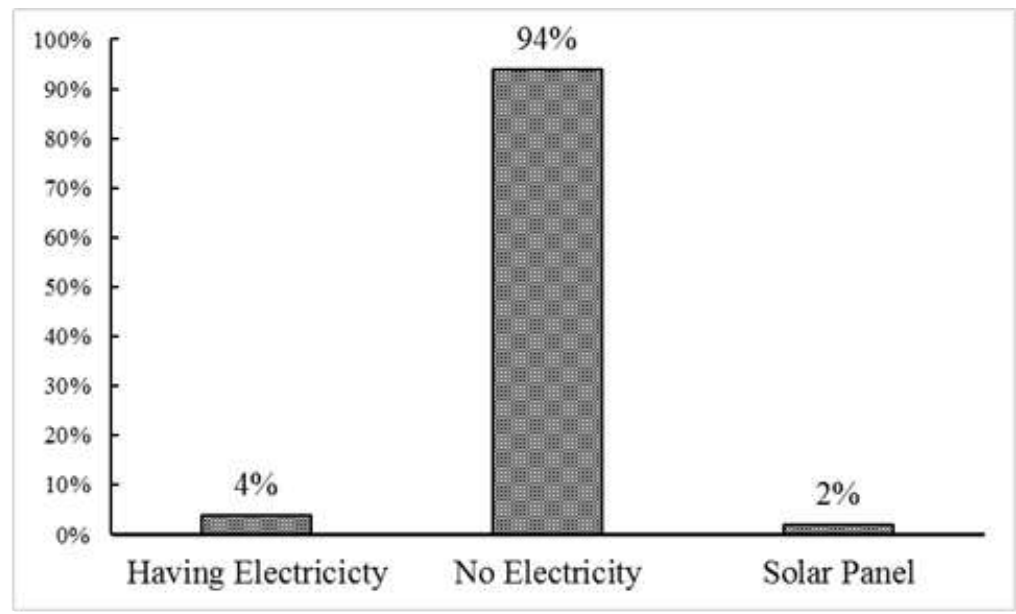

Figure 8. Electricity facilities. 


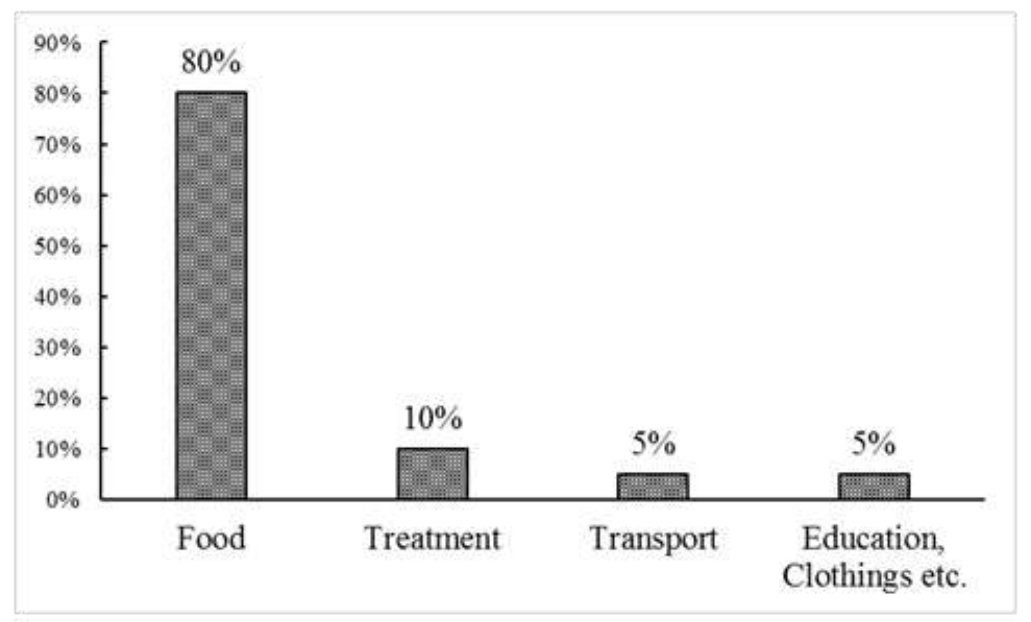

Figure 9. Area of expenses.

Table 1. Different types of net found in the Patharghata Fishery Ghat, Chittagong.

\begin{tabular}{|c|c|c|c|c|}
\hline $\begin{array}{l}\text { Different nets based } \\
\text { on their operation }\end{array}$ & $\begin{array}{l}\text { Net Local } \\
\text { name }\end{array}$ & $\begin{array}{l}\text { Mesh size } \\
\text { (inches) }\end{array}$ & $\begin{array}{l}\text { No. of } \\
\text { fishermen } \\
\text { needed for } \\
\text { handling }\end{array}$ & Species caught* \\
\hline \multirow[t]{9}{*}{$\begin{array}{l}\text { Large Mesh Drift } \\
\text { Gill Nets (DGNs) }\end{array}$} & Lakkha Jal & $12-16$ & $15-20$ & $\begin{array}{l}\text { Lakkha/Lakhua, Datina, Ranga Chokkha, Chapa, } \\
\text { Modhu Guizza, Med Gada/Medha, Chembali, koral, } \\
\text { Ranga Koi, Hangor, Kamot, Haush, Maitta, Tuna } \\
\text { Machh }\end{array}$ \\
\hline & Lal Jal & $4-8.5$ & $3-4$ & $\begin{array}{l}\text { Illish, Maitta, Rupchanda, Tekhchanda, Gorachanda, } \\
\text { Akali Chanda, Churi, Poa, Tak Chanda, Ranga Koi, } \\
\text { Chulerdandi, Loittya, Hangor,, Kamot, Haush, } \\
\text { Choukka Hangor, Talia, Burum Maitta, Shurma } \\
\text { Maitta, Rocket Maitya }\end{array}$ \\
\hline & $\begin{array}{l}\text { Char Shuta } \\
\text { Jal }\end{array}$ & $2.5-3$ & $15-20$ & $\begin{array}{l}\text { Illish, Maitta, Rupchanda, Tekhchanda, Gorachanda, } \\
\text { Akali Chanda, Churi, Poa, Tak Chanda, Ranga Koi, } \\
\text { Chulerdandi, Loittya, Hangor,, Kamot, Haush, } \\
\text { Choukka Hangor, Talia, Burum Maitta, Shurma } \\
\text { Maitta, Rocket Maitya }\end{array}$ \\
\hline & Vasha Jal & $4-4.5$ & $5-6$ & Illish \\
\hline & Ton Jal & $2.5-3$ & $3-4$ & Illish, Rita, Bata, Chepta Bailla \\
\hline & Illish Jal & $3-3.5$ & $7-10$ & Illish \\
\hline & Maitta Jal & $4-4.15$ & $6-8$ & Maitta, Churi, Chotpoti \\
\hline & Hangor Jal & 12 & $15-20$ & $\begin{array}{l}\text { Hangor, Kamot, Lakkha/Lakhua, Titamarmari, } \\
\text { Haush, Saplapata }\end{array}$ \\
\hline & Moda Jal & 12 & $10-15$ & Datina, Lakkha/Lakhua \\
\hline \multirow[t]{2}{*}{ Trammel Net } & Pondora Jal & 1.5 & $6-8$ & Chulardandi \\
\hline & Tong Jal & $3-4$ & $1-2$ & Illish \\
\hline $\begin{array}{l}\text { Marine Set Bag } \\
\text { Nets (MSBNs) }\end{array}$ & $\begin{array}{l}\text { Behundi/ } \\
\text { Bendi Jal }\end{array}$ & $\begin{array}{l}\text { Not } \\
\text { definite }\end{array}$ & & Loiittya, Chingri, Poa \\
\hline
\end{tabular}

*Encyclopedia of Flora and Fauna of Bangladesh-Marine Fishes, 2009. Asiatic Society of Bangladesh. 
Table 2.The Specifications of Longlines.

\begin{tabular}{|c|c|c|c|c|c|}
\hline \multirow{2}{*}{$\begin{array}{l}\text { Fishing } \\
\text { Gear }\end{array}$} & \multirow{2}{*}{$\begin{array}{l}\text { Length } \\
\text { (Meter) }\end{array}$} & \multirow{2}{*}{$\begin{array}{l}\text { Operating } \\
\text { Depth (Meter) }\end{array}$} & \multicolumn{3}{|c|}{ Main targeted Species } \\
\hline & & & Local Name* & English Name & Scientific Name* \\
\hline \multirow[t]{7}{*}{ Longlines } & $15-60$ & $10-30$ & SadaPoa & Donkey Croaker & Pennahia anea \\
\hline & & & Kala Datina & $\begin{array}{l}\text { Black Spotted } \\
\text { Croaker }\end{array}$ & $\begin{array}{l}\text { Protonibea } \\
\text { diacanthus }\end{array}$ \\
\hline & & & Lambu, BoroPoa & Bronze Croaker & $\begin{array}{l}\text { Otolithoides } \\
\text { biauritus }\end{array}$ \\
\hline & & & RupaliPoa & Belanger's Croaker & Johnius belangerii \\
\hline & & & Kata Machh & $\begin{array}{l}\text { Threadfin Sea } \\
\text { Catfish }\end{array}$ & Arius arius \\
\hline & & & Moschh & River Catfish & Arius jatius \\
\hline & & & Kala Poa & Sin Croaker & Johnius dussumieri \\
\hline
\end{tabular}

*Encyclopedia of Flora and Fauna of Bangladesh-Marine Fishes, 2009. Asiatic Society of Bangladesh.

Table 3.The annual income of different fishermen.

\begin{tabular}{llll}
\hline Fishermen Type & Percentage (\%) & Annual Income (Taka) & Annual Expenses (Taka) \\
\hline Main Fishermen & 80 & $50,000-70,000$ & $50,000-60,000$ \\
Sub Boatmen & 15 & $70,000-1,00,000$ & $70,000-90,000$ \\
Main Boatmen & 5 & $>1,00,000$ & $1,00,000$ \\
\hline
\end{tabular}

\subsubsection{Pondora Jal}

Pondora Jal is not so extensively used compared to other nets. The length and width of the net are $350 \mathrm{~m}$ and 8 $\mathrm{m}$, respectively. The mesh size is very small which varies within 1.5 inches. Small sized fishes and shrimps are harvested by the net. Typically, 6-8 fishers are needed to operate the net.

\subsubsection{Tong Jal}

Tong Jal is very small type of net which has a length of only $10 \mathrm{~m}$ and width of $6 \mathrm{~m}$. The mesh size of the net is 3 to 4 inches. This net is mainly used in estuarine river. Only 1-2 men can operate the net. This net is also used to catch medium sized Hilsha Shad.

\subsubsection{Marine Set Bag Nets (MSBNs)}

Marine set bag nets (MSBNs) are pocket type net having large mouth and narrow tail. Mesh size of the net also becomes smaller gradually from head to tail. Nets are kept fixed in one place in favor of current for 5 to 6 months by using bamboo and wooden pillars. The fishermen stay in the fishing place with their boats and collect fish time to time from the nets. Locally the nets are called Behundi Jal with the length ranging from 8 to $40 \mathrm{~m}$, mouth opening of 5 to $30 \mathrm{~m}$, and cod end mesh size of 12-25 mm. MSBNs are used by both mechanized and non-mechanized crafts. Generally the non-mechanized boats use smaller MSBNs and vice-versa. Most of the fish and shrimp species caught by MSBN are pre-adults and adults. Loitya (Bombay duck), Chingri (Shrimp), Poa (Goatee Croaker) are commonly harvested species by this type of net.

\subsubsection{Some less commonly used nets}

There are some other types of nets which are less importantly used in the Fishery Ghat mainly as side nets in the boats. The mesh sizes of these nets are not definite but their efficiencies are very high.

\subsubsection{Current Jal}

These nets are made up of nylon twine with the average length and width of about $25 \mathrm{~m}$ and $5 \mathrm{~m}$, respectively. The mesh size of this net is very small but elasticity is high. Therefore, various sizes of fishes such as Hilsha ( $T$. Ilisha), Nailya (Dussumieria acuta), Loittya (H. nehereus) and Edur Leizza (Coryphaenoides woodmasoni) etc. are trapped by entangling their gill into the net.

\subsubsection{Baba Jal}

Various kinds of species are caught by the net. The length ranges from 150 to $250 \mathrm{~m}$ and the width $4 \mathrm{~m}$ having mesh size of 3 inches. The net is made of 'Nali Shuta' which is very thin twine and the main species caught by 
the net are Hilsha (T. Ilisha), Nailya (D. acuta), Loittya (H. nehereus) and Edur Leizza (C. woodmasoni), Phaisa (Thryssa mystax), and Churi (Eupleurogrammus mulicus).

\subsubsection{Chikon Jal}

Chikon Jal is similar to Baba Jal and it is also made of 'Nali Shuta'. The length and width of the net varies from 900 to $1000 \mathrm{~m}$ and 7 to $8 \mathrm{~m}$, respectively, with the fixed mesh size of 4 inches. Similar kinds of fish species are caught by this net to that of Baba Jal additionally including Kata Machh (Arius arius), Chapa (Scomberoides commersonnianus), Maittya (Rastrelliger kanagurta) etc.

The use of different kinds of nets varies with seasons. It is obvious to use Illish Jal during the peak season of Hilsha Shad. Figure 3 showed the seasonality map of the use of different nets.

\subsubsection{Longlines}

Longline is applied to catch the demersal or pelagic fishes. In this method, the gear involves setting out a long length of line of about 15 to $60 \mathrm{~m}$ (Table 2). Exceptionally sometimes the longline are used of about several kilometers in length. One end of the line is held by a heavy anchor and the other end marked by a flag is positioned by a heavy weight. Baited hooks are attached in the line after every 0.60 to $1.80 \mathrm{~m}$ length. Longlines are used between $10 \mathrm{~m}$ to $30 \mathrm{~m}$ depth and the hooks are baited with prawns, crabs, and entrails of fish. The common species targeted by longlines are Pennahia argentata, Johnius belangerii, Protonibea diacanthus, Otolithoides pama.

\subsubsection{Fishing craft}

The speciality of the Fishery Ghat is that only single type of about 700-800 fishing boats are available in the ghat (Figure 4). All the boats are mechanized and operated by marine engines. These are called fishing boat or fishing trawler. Although they are called fishing trawler but they do not have enough facility as real fishing trawlers have. These trawlers are made up of wood of 'Gorjon' and 'Goda' trees mainly used for artisanal marine fishing. The length, width, and height of the boats ranges from 40-52 feet, 10-15 feet, 12-15 feet, respectively. The boat engines are operated by diesel as fuel and the fuel consumption ranges from 200 to 250 liters/engines/24 hours journey. The number of fishermen per boat varies from 20 to 24 persons. The carrying capacity of medium sized boat is 8-12 metric tons whereas for larger ones the capacity increases from 16 to 20 metric tons. There is cooking facility and a toilet, in the front platform specific place for keeping nets and under the platform two cold storage rooms are available in the trawlers. Usually the fishermen from the Fishery Ghat go for 10-15 days trip to the open sea for fishing.

\subsection{Socio-economic status of the fishermen}

In the study area, there were about 15000 fishermen who are directly involved in fishing activities. Randomly 53 fishermen were interviewed in different places such as in the boats, in the landing center, in the bazar and in the tea shop of the area. Results attempted to analyze the prevailing social and economic condition of the fishermen of the Patharghata Fishery Ghat. Data collected were mainly of about age group, religion, family type, education level of fishermen, housing condition, electricity facilities, alternative occupation, annual income and expense etc.

\subsubsection{Personal information}

The fishermen were interviewed about their personal matters through which an understanding regarding their livelihood status could be obtained.

\subsubsection{Age group and sex}

In general older aged fishermen means more experienced and more efficient. The ages of the interviewee ranged from 11 to 60 years. Boatmen were the most experienced person in the boat and they were likely to be the most aged person among the crews. The age variations were categorized into five groups such as very young (11-20 years), young (21-30 years), middle aged (31-40 years), aged (41-50 years), and old (51-60 years). Data explained that the highest number (31\%) of fishermen were from two age groups, one from 21-30 years and another from 31-40 years which indicated that young and middle aged fishermen are dominant in the Ghat (Figure 5). Out of 53 respondents, all were male which revealed that fishing is exclusively done by the male in this area. 


\subsubsection{Religion}

The fishing communities of Bangladesh include people of various castes, creed and status. It was found that Muslims were featuring as the absolute majority among sampled fishermen. Among 53 fishermen only five fishermen were Hindu and the rest of them were Muslim, meaning that $91 \%$ of the fishermen were Muslim, and the rest $9 \%$ was Hindu.

\subsubsection{Locality of the fishermen}

The study revealed that the fishermen of the Ghat are not local. They came from other districts for the betterment of their livelihood. The fishermen from three districts such as Noakhali, Barisal and Bhola were dominating in the region. About 60\% of the fishermen were from Greater Noakhali, 25\% were from Bhola, $17 \%$ were from Barisal and the rest were from different districts (Figure 6).

\subsubsection{Marital status and family type}

Majority of the fishermen were married. Even some fishermen of age below 20 years were married. More than $91 \%$ of the fishermen were married and the rest were unmarried. No divorced fishermen were found. Two types of family size were found to maintain by the fishermen, one was nuclear family- married couples with children and another was joint family- group of people related by blood or by law. However, it was found that fishermen like to live in joint family making good relation with their close relatives compared to nuclear family living only with their wives and children. About 54\% families were found joint and rest $46 \%$ was nuclear. The average members of the nuclear and joint families were 3.78 and 7.83 per household, respectively.

\subsubsection{Literacy status of the fishermen}

The level of literacy is generally considered as an index of social advancement of a community. The literacy level of the fishermen of the Fishery Ghat was very low. The majority was illiterate whereas only few fishermen had their primary level of education and very few could only write their names and give a signature. Children were also found continue their education up to primary level or 5th class and onwards they dropped in and engaged to different kind of works to earn some money. Very few fishermen entered in the secondary class but did not complete their S.S.C. degree. The study revealed that $67 \%$ fishermen had hardly any kind of education, whereas, $27 \%$ fishermen had primary and 6\% fishermen had secondary level of education (Figure 7).

\subsubsection{Way of living}

Way of living of an individual includes ones housing condition, having electricity, annual income and expense and so on. Housing condition is an important indicator of the economic condition of the fishermen.

\subsubsection{Housing condition and electricity facility}

Most of the fishermen lived in very poor housing conditions. All the fishermen had tin shed house that means the houses are either semi pakka or tin shed- made of tin. Most of the fishermen (94\%) had no electricity supply in their houses as they were living in so remote areas (such as in Hatya, Ramgoti) where electricity facilities had not reached yet. Only $4 \%$ of fishermen had the privilege of electricity supply. The study revealed that although some of the fishermen had financial capability to use electricity but because of unavailability of electricity supply they (2\%) were using solar panel alternatively (Figure 8).

\subsubsection{Annual income, expense and savings}

Level and sources of income are important socio-economic characteristics of a community. The study revealed that annual income of the main fishermen (about $80 \%$ of the total fishermen) was between Tk. 50,000 and 70,000. The sub boatmen had an annual income between Tk. 70,000 and 100,000 and this group covers $15 \%$ of the total number of the fishermen of the Ghat. The annual income of main boatmen was above Tk. 100,000 (Table 3). The study also reported that the annual expenses of the main fishermen were between Tk. 50,00060,000 , whereas, such expenses of the sub and main boatmen were between Tk. 70,000-90,000, and about Tk. 100,000 , respectively (Table 3 ).

Household income spent by the fishermen was on different fields such as food, clothing, healthcare, education, housing etc. The main spending areas were for food and treatment of the fishermen family members. The statistics showed that the fishermen spent more than $80 \%$ of their income for food supply, $10 \%$ for treatment, $5 \%$ for transport, and rest 5\% to fulfill other basic needs of the family members such as education, clothing etc. (Figure 9). The study also found that they had no savings and sometimes in yearly expending basis they had to 
spend more money than their income. During that time they borrowed money from others such as aratders or wholesalers.

\subsubsection{Alternative occupation}

The fishermen were entirely dependent on fishing employment. They had embraced it as not only their traditional occupation but also as a cultural one. So they had lack of expertise in other fields of occupation. In the Fishery Ghat, most of them were Hilsha catching fishermen and during off season of Hilsha, they shifted to catch other species like Lakhua, Bombay duck, Datina etc. Whenever natural disasters took place, they had to come back to the shore and to wait for the situation getting safe. Due to injury or physical disability, some fishermen had to go back to home and changed their profession to become daily labor or rickshaw puller.

\section{Discussion}

The Patharghata Fishery Ghat is one of the most important fish landing centers of Bangladesh. Huge amount of Hilsha fish is landed every day during peak season. Besides Hilsha, a large amount of other commercially important marine fish species viz. Maitta, Datina, Loitta, Coral etc. are also landed which introduced the landing center as highly important not only from the economic point of view but also as a place of employment opportunity of thousands of fishermen from different regions of Bangladesh. To catch these species, different types of fishing gears are used by the fishermen.

The gears and craft are classified on the basis of the multitude of fishing devices and techniques (Von, 1984). The study revealed that mainly three groups of nets are found in the Ghat, which are Large Mesh Drift Gill Nets (DGNs), Trammel Nets, and Marine Set Bag Nets (MSBNs). DGNs are the most dominant group containing 9 types namely Vasha Jal, Ton Jal, Illish Jal, Lakkha Jal, Lal Jal, Maitta Jal, Hangor Jal, Moda Jal, Char Shuta Jal. Among them the three most common types of nets are Lakkha Jal, Lal Jal, and Char Shuta Jal. In Megna river estuary, 5 types of gill nets are used (Siddique et al., 2013) and similar types are also used by the fishermen of Hatiya Upazila of Noakhali district (Azam et al., 2014). Gill nets have also been used to catch fish in South West Bengal region of India in three ways: a. wedged- held by the mesh around the body, b. gilled-held by mesh slipping behind the opercula, and/or c. tangled- held by teeth, spines, maxillaries, or other protrusions without the body penetrating the mesh (Pijush et al., 2014). In the Fishery Ghat, more types of gill nets are found because of its effectiveness. There is no regulation and monitoring about the mesh size, twine strength, as well as net length and depth of these gill nets by the fisheries management and enforcement agencies to reduce by catch of non-target species. Marine Set Bag Nets (MSBNs) or Behundi Jal are used to catch Loitta, Chingri, Poa etc. in the study area. Behundi is a fixed bagnet with a rectangular mouth. It is harmful for marine ecosystem because of its irregular mesh size; it catches all sizes of fishes. Around Cox's

Bazar, these nets are used in the sea during October to March to catch bigger fishes of high economic value such as pomfrets, large croakers and Spanish mackerel (BOBP, 1985). Trammel nets are not so important to catch fish in the study area as most of the important fish species are caught by DGNs and MSBNs. However, nearly $70 \%$ of the total prawn catches in Tamil Nadu in India are caught by the traditional Trammel nets (Pillai et al., 1994).

Mesh size has direct impact on the diversity of the fish. Smaller meshed nets are becoming threat for the marine fisheries resources because undesirable juveniles of different species are caught by the nets. In the Patharghata Fishery Ghat, the mesh sizes of different drift gill nets ranged from 2.5 to 12 inches; whereas, in India, the mesh sizes of nets are smaller ranges from 0.4 to 4.7 inches (Pillai et al., 2000). To conserve fish resources the government of Myanmar increased the minimum mesh size for prawn trawl nets to 1.5 inch $(3.8 \mathrm{~cm})$ and finfish trawl nets to 2.5 inches $(6.35 \mathrm{~cm})$ from September 2010 (ILO, 2015).

Fishing craft is a specialized boat, ship or other vessel used for fishing. In Bangladesh, there are about 3,06,642 fishing crafts (including 141 trawler, 43,960 traditional and 21,433 mechanized boat) engaged in fish transportation (DoF, 2012). In the Fishery Ghat, single type of wooden mechanized fishing boats is found which are also known as fishing trawlers. The length of the boat ranges from 40-52 feet and width is 10-15 feet. The general height of the boats ranges from 12-15 feet. The average size of mechanized fishing boats operated in Indian coast is much larger than the fishing boats of the Chittagong Fishery Ghat. The length of these boats ranges from 60-73 feet and width is 40-46 feet (Pillai et al., 2000), whereas, the length of the fishing vessels of offshore fishery of Thailand is more than 30 feet long (ILO, 2015). Locally the fishing crafts are specifically designed and constructed for fishing in the sea. Hence it is difficult to classify the crafts according to the net used because mostly fishermen use same boat for operating different nets. The principal considerations given to the development of fishing boat construction are higher catching power, smaller number of crews, and reduced operational costs. All the fishing vessels were mechanized in the study area; whereas, only 50\% of the mechanized fishing boats were operated in the lower region of Megna river (Moula et al., 1993). 
Another purpose of this study was to determine the socio-economic status of fishermen of the Patharghata Fishery ghat, Chittagong. Especial emphasis was given on such variable namely age, education, family size, annual income, family members, electricity facilities and other socio economic issues.

The study explained that the highest numbers of fishermen (a total of 62\%) were in two age groups, one from 21-30 years and other between 31-40 years indicating that young and middle aged fishermen are dominant in the Ghat. Similar ages of fishermen were found at the seasonal flood plain (beels) at Bagmara Upazila in Rajshahi, where most of the fishermen were at the age group of 31-40 years (Hossain et al., 2009; Ali et al., 2008). Another study showed that $50 \%$ of the fishermen belonged to the age group of 31 to 40 years of the fishing community of the old Brahmaputra river (Kabir et al.,2012) suggesting that young and middle aged fishermen are two most common groups which are involved in fishing in both marine and freshwater fisheries sectors in Bangladesh. The average members of the nuclear and joint families were found 3.78 and 7.83 per household, respectively in the Ghat. In Jamuna river area similar type of family structure such as 5.26 persons/household of nuclear family and 7.87 persons per household of joint family were found (Shahjahan, 2003). It is obvious that fishermen communities in Bangladesh have higher tendency towards joint family because of their poverty.

From the study, it was found that majority (91\%) of fishermen of the Chittagong Fishery Ghat area was married and only 9\% were unmarried. Result by Ahmed (1996) in Tangail, Mannu (1999) in Kuakata and Shamima (2000) in Gallamari also depicted that the fishermen communities of those areas were also dominated by married people such as $94 \%, 92 \%$, and $70 \%$, respectively. Education level of a community directly influences their socio-economic condition. In the study area, maximum fishermen $(67 \%)$ were illiterate, only $6 \%$ had secondary level of education and the rest $(27 \%)$ had primary education level. Same result was found in the fishermen of Jamuna river area where, $66.33 \%$ fishermen were illiterate, $32.67 \%$ were up to primary level, and $5 \%$ only had secondary level of education (Shahjahan, 2003). It is a common phenomenon in Bangladesh that most of the fishermen cannot even write their names. It was observed that $80 \%$ of fishermen had lowest annual income (BDT 50,000-70,000); whereas, $15 \%$ of fishermen had moderate annual income (BDT 70,000-100,000). Only 5\% of the fishermen had an annual income of above BDT 100,000. On the other hand fishermen from inland water bodies had comparatively higher annual income to the fishermen from the Fishery Ghat. Islam et al. (2013) found that the annual income of the fishermen from Monirampur upazila of Jessore district was about BDT $1,15,0500$. The present study revealed that about $94 \%$ of fishermen had no electricity facilities; whereas, only $4 \%$ and $2 \%$ of fishermen had electricity and solar panel, respectively. However, various studies about the socio-economic status of fishermen in different inland localities found that communities of inland water bodies enjoy more basic facilities compared to marine fisheries community. Ali et al. (2008) and Hossain et al. (2015) recorded that about $62 \%$ and $36 \%$ of the fishermen in Bagmara upazila of Rajshahi district and Punarvaba river area of Dinajpur district had electricity facilities, respectively. The fishermen of the Chittagong Fishery Ghat were mainly from Char areas of southern area of the country where no electricity facilities had yet been reached. That is why they had to live without electricity.

\section{Conclusions}

There are different types of fishing nets used in the Chittagong Fishery Ghat to catch different fish species and most of them are Large Mesh Drift Gill Nets (DGNs). The mesh size of the nets varied from small (less than 2 inches) to very big (more than one foot) and therefore fishes of various sizes are caught. Of the nets three types (Lakkha Jal, Lal Jal, Char Shuta Jal) are most commonly used to catch variety of species including Hilsha, Lakhua, Datina, Maitta etc. But there is single type of fishing craft only found in the Fishery Ghat. This is causing a great trouble to the fishermen in handling different types of nets from a single type of craft because each type of net has specific length and width and most importantly, different number of man power is needed for different types of net. Therefore 'post-harvest-loss' has been reported (Alam, 2010). Moreover, Current Jal, a devastating type of fishing net, is used in the Ghat during off season to catch smaller sized Hilsha fish and therefore the abundance of Hilsha fish is affected. The Marine Set Bag Nets locally called Behundi Jals are also found to catch different types of fish species. These types of nets have greater efficiency to catch fish, but the major disadvantages of the nets are the indefinite mesh sizes. So fishes of all sizes are caught by the nets and most of them are unwanted. The fish diversity is directly affected by the use of these types of nets. These conditions are taking place due to the lack of intervention of local authority. Proper guideline and management policy will easily reduce those problems. On the other hand, socio-economic condition of the fishermen is not satisfactory and is not improving with the time due to loan of high interest, illiteracy, worse weather condition, more intermediaries in the marketing chain etc. If fishermen cannot get education, loan of low interest, proper health and sanitation facilities, their socio-economic condition will never be improved. Government and nongovernment organizations have to take proper steps to improve their socio-economic condition by effective planning. 
There are some limitations during conducting this study. These limitations can be concluded as follows.

a) Almost all the fishermen are illiterate. So that it was difficult to make them understand about the objectives of the study.

b) Most fishermen hesitated to answer firstly.

c) In most cases information's (data) were based on their experiences.

d) Data were collected only for two months and there had been a possibility of the seasonal variability of the use of different gears.

\section{Acknowledgements}

The authors gratefully acknowledge Upazila Fisheries Officer (UFO), Chittagong; fishermen and intermediaries in the study area, for providing valuable information.

\section{Conflict of interest}

None to declare.

\section{References}

Ahmed NU, 1996. Report of the fishermen's socio-economic survey. Fisheries survey and Monitoring program, Department of fisheries, Tangail. 1p.

Akter H, MR Islam and MB Hossain, 2012. Fecundity and Gonadosomatic Index (GSI) of Corsula, Rhinomugil corsula Hamilton, 1822 (Family: Mugilidae) from the Lower Meghna River Estuary, Bangladesh. Glob. Veter., 9:129-132.

Alam AKMN, 2010. Post-harvest loss reduction in fisheries in Bangladesh: a way forward to food security. National Food Policy Capacity Strengthening Programme (NFPCSP).

Alam MF and TK Das, 2007. Fishermen and Community Based Fisheries Management in Bangladesh: A Study on Conflict and Cooperation, Dhaka: Chayanica.

Ali MH, MD Hossain, ANGM Hasan and MA Bashar, 2008. Assessment of the livelihood status of the fish farmers in some selected areas of Bagmara upazilla under Rajshahi district. J. Bangladesh Agril. Univ., 6: 367-374.

APCAS, 2016. Fisheries Statistics in Bangladesh: Issues, Challenges and Plans. Asia and Pacific Commission on Agricultural Statistics/16/6.3.2.

Azam AKMS, D Saha, M Asadujjaman, KR Mahbub and MH Minar, 2014. Fishing Gears and Crafts Commonly Used at Hatiya Island: A Coastal Region of Bangladesh. Asian J. Agril. Res. 8: 51-58.

Bennett E and Chattermoul, 1998, cited in Ghani A, N Ahmed, F Ahmed, A Kashem, 2008. Two Case Studies on Water Bodies and Livelihood of Haor Areas, Sylhet: IDEA.

Bob P, 1996. Inland Fisheries and Property Rights in Bangladesh- Exploring the Case for Co-management. Asia- Pacific J. Env. Dev. 3.

BOBP, 1985. Marine small-scale Fisheries of Bangladesh: a general description. Food and Agriculture Organization of the United Nations (FAO).

Chakraborty SC, MA Hossain and ME Hoq, 1995. Traditional inland fishing methods in Bangladesh. J. Asiat. Soc. Bangladesh Sci. 21: 19-27.

DoF, 2012. Fish fortnight compendium 2012. Department of Fisheries, Ministry of Fisheries and Livestock, Dhaka, Bangladesh, 144p.

Ghani A, N Ahmed, F Ahmed and A Kashem, 2008. Two Case Studies on Water Bodies and Livelihood of Haor Areas, Sylhet: IDEA.

Hameed MS and MR Boophendranath, 2000. Modern Fishing Gear Technology, Das Publishing House, Delhi, $3 \mathrm{p}$.

Hossain FI, MI Miah, MHA Hosen, R Pervin and MR Haque, 2015. Study on the Socio-Economic Condition of Fishermen of the Punorvaba River under Sadar Upazila, Dinajpur. J. Fish., 3: 239-244.

Hossain MI, C Siwar, MB Mokhtar, MM Dey and AH Jaafar, 2009. Socio-economic Condition of Fishermen in Seasonal Floodplain Beels in Rajshahi District, Bangladesh. Res. J. Soc. Sci., 4: 74-81.

Hussain MM, 2010. The Socio-economic Situation and Occupational Challenges of Fishermen in Sylhet. SUST Studies, 15: 94-103.

ILO, 2015. Value chain analysis and competitiveness strategy: marine capture fisheries: Myeik and Yangon, Myanmar / International Labour Organization, ILO Liaison Officer for Yangon Myanmar.

Islam MR, MN Hoque, SM Galib and MA Rahman, 2013. Livelihood of the fishermen in Monirampur Upazila of Jessore district, Bangladesh J. Fish., 1: 37-41.

Kabir KMR, RK Adhikary, MB Hossain and MH Minar, 2012. Livelihood Status of Fishermen of the Old 
Brahmaputra River, Bangladesh. World Appli. Sci. J. 16: 869-873.

Mannu MU, 1999. Jeleder Sukh Dukh. The Daily Janakayrtha. 22 August 1999.

Moula G, Y Mahmud, MGM Alam and MA Hossain, 1993. Fishing Crafts and Gears of Meghna River. Progress. Agric. 4: 59-65.

Pijush P, M Basudev and RG Chandra, 2014. Crafts and Gears operated in brackish water fed canal for harvesting Fishes in different Seasons to maintain livelihood of the Fishermen communities. Inter. Res. J. Bio. Sci., 3: 8-13.

Pillai PKM, G Balakrishnan, V Phillpose and V Rajendran, 2000. An appraisal on the marine fishing craft and gear of the Indian coast. Pillai VN and NG Menon, Ed. Marine Fisheries Research and Management. Central Marine Fisheries Research Institute. Kerala, India.

Pillai PKM, G Balakrlshnan and K Alagaraja, 1994. Present status of marine fisheries of Tamllnadu and Pondicherry. Mar. Fish. Infor. Serv. T\&E Ser., 129: 1-12.

Shahjahan M, 2003. Study on the fisheries on the socio-economic condition of the fishermen of the Jamuna River. An M.S. thesis to the Department of Fisheries Management, Bangladesh Agricultural University, Mymensingh.

Shamima SH, 2000. Socio-economic condition of fishing community: Gallamary fish market, Khulna. B.Sc. thesis. Fisheries and Marine Resource Technology Discipline, Khulna University, Khulna.

Siddique, AB, D Saha, M Rahman and MB Hossain, 2013. Fishing Gears of the Megna Estuary of Chandpur Region, Bangladesh. Tren. Fish. Res., 2: 2319-4758.

Uddin N, 2000. The Fishermen Community of Maheshkhali Island: An Anthropological Study, Dhaka: Environmental Conservation Management Centre (ECOMAC).

Von BA, 1984. Fish Catching Methods in the World. Fishing News Books Ltd., London, 418p. 